\title{
De la pobreza como problema a la pobreza como virtud
}

\author{
FRANCISCO XAVIER SÁNCHEZ HERNÁNDEZ* \\ Tecnológico de Monterrey (México) \\ franciscox.sanchez@tec.mx
}

\begin{abstract}
Resumen
Vivimos en un mundo cada vez más polarizado entre ricos y pobres. Entre un pequeño grupo de personas que concentra y controla la riqueza mundial, y la gran mayoría de la población que no cuenta con las condiciones indispensables para poder vivir. Por otra parte, la globalización económica promueve un modelo de humanidad basado en el consumismo. El ser humano ha identificado la búsqueda de la felicidad con el comprar y adquirir los nuevos modelos que la publicidad impone. Nos estamos acabando al planeta -incluyendo a la humanidad-y las consecuencias son evidentes: calentamiento global, contaminación, extinción de especies, violencia, migración, etc. Por otra parte, la acumulación de recursos en manos de unos cuantos es algo que también destruye a los ricos, los deshumaniza. Consideramos por tanto que si bien la pobreza, como carencia de lo indispensable para poder vivir dignamente, es un problema que debemos solucionar; por otra parte, hay otro tipo de "pobreza" entendida como virtud, que nos ayuda a vivir más plenamente, y es aquella que nos proporciona libertad para centrarnos en lo esencial: la familia, la humanidad, el mundo y Dios. El objetivo del presente trabajo es pasar de la pobreza como problema a la pobreza como virtud.

Palabras clave: Pobreza, Injusticia, Libertad, Virtud, Levinas.
\end{abstract}

\section{From poverty as a problem to poverty as a virtue}

\begin{abstract}
We live in a world where the gap between the rich and the poor is increasing. In a world where a small group of people concentrates and controls the wealth, and the rest of the population is lacking the indispensable conditions for living. On another hand, economic globalization promotes a model of humanity based on consumerism. Human beings have related search of happiness with acquiring commodities and models imposed by advertising. We are destroying the planet-including bumanity-and the consequences are evident: global warming, pollution, endangered species, violence, migration, etc. In addition, accumulating resources is dehumanizing and destroying the wealthy societies. We consider, that poverty understood as lacking financial resources is a problem that needs a resolution; but also, poverty, understood as virtue, belp us to live fully and provides freedom, so we can focus on the essentials: family, humanity, the world and God. The objective of this work is to pass from poverty as a problem, to poverty as a virtue.
\end{abstract}

Key words: Poverty, Injustice, Freedom, Virtue, Levinas.

* Licenciado en Teología y Doctor Canónico en Filosofía por el Instituto Católico de París y Doctor en Filosofía por la Universidad de Paris IV, La Sorbona. Entre sus publicaciones destacan los libros La verdad y la justicia. La llamada y la respuesta en la filosofía de Emmanuel Levinas (2006); La vérité et la justice, dans la philosophie d'Emmanuel Levinas, L'Harmattan (2009); La justicia. Una respuesta a la verdad del otro (2012); Filosofía de la religión. Reflexiones (2014); Sí mismo como otro. Introducción a la hermenéutica de Paul Ricoeur (2017); y Caminos de justicia en y desde América Latina (2018).

Recibido: 23/Enero/2019 - Aceptado: 7/Mayo/2019 


\section{INTRODUCCIÓN}

La pobreza económica no es solo uno de los grandes males que sufre la humanidad, sino que está en el origen de muchos otros males: hambruna, desnutrición, analfabetismo, migración, desempleo, etc. La pobreza económica es un mal que debemos evitar. Y por otra parte la abundancia de los ricos, el derroche de sus lujos y la superficialidad de sus vidas, es también un mal que los destruye porque los vuelve esclavos de sus posesiones. Por lo tanto, si por una parte, hay que combatir a la pobreza económica que destruye a la mayor parte de la población, por otra parte, hay que buscar un tipo de pobreza -llamémosle virtud o pobreza espiritualque venga a liberar al hombre para buscar lo realmente necesario: la vida, la familia, los amigos, la paz, la justicia. Es importante que valoremos a la pobreza elegida y no impuesta no como un problema sino como una virtud.

La pobreza puede entenderse, de manera muy general, a partir de dos grandes dimensiones: la pobreza espiritual y la material. $\mathrm{O}$, dicho de otra manera, la espiritual o invisible -dimensión personal-y ligada a la ética y a la religión; y la material o visible - dimensión social- es decir la concreta y ligada a la economía y a la política. Dentro de este último tipo de pobreza material entran gran variedad de expresiones como pueden ser: la pobreza alimentaria, cultural, sanitaria, educativa, etc. Diferentes tipos de pobreza material o visible, que tienen su raíz en la mala administración de nuestra casa común que es el planeta. Es decir, en la mala administración de la economía. Ya que como lo dice la etimología misma de la palabra "economía" (oikonomos), la economía es la ciencia que busca la administración del hogar. "Si la economía es el campo de la producción, de la distribución y del consumo de bienes y servicios, y si la ética es la reflexión acerca de lo que debemos hacer. Individual o colectivamente, entonces la ética económica es una disciplina muy antigua" (CantoSperber, 2011: 466).

En esta reflexión nos referiremos en particular a la pobreza económica, a la que consideramos raíz de todas las demás formas de pobreza en el mundo. Consideramos que la pobreza económica es un desafío ético para las sociedades contemporáneas. Nos parece que hasta ahora la economía ha estado ligada a la política, es decir a la visibilidad del ser humano (su materialidad), y consideramos importante buscar otro fundamento a la economía que surja de la ética (de esta dimensión llamémosle invisible, o más bien dicho espiritual del ser humano). Una economía que surja de la dignidad de la persona humana, con base ética, y que busque combatir la pobreza en el mundo, y no una economía que surja del afán de acumular 
riqueza de manera egoísta. La pobreza en el mundo es uno de los principales males que aquejan a la humanidad. En la página oficial del Banco Mundial podemos leer la siguiente información:

Los avances en cuanto a la reducción de la pobreza han sido notables en las últimas décadas. El mundo logró la meta del primer objetivo de desarrollo del milenio (ODM) de disminuir a la mitad para 2015 la tasa de pobreza registrada en 1990, y lo consiguió en 2010, cinco años antes de la fecha prevista. Pero pese a este logro, la cantidad de personas que vive en condiciones de pobreza extrema en el mundo sigue siendo inaceptablemente elevada. De acuerdo con las estimaciones más recientes, el $17 \%$ de la población del mundo en desarrollo vivía con menos de US $\$ 1,25$ al día en 2011, cifra inferior al $43 \%$ de 1990 y al $52 \%$ de 1981 .

Estos datos optimistas del Banco Mundial, de que se ha logrado reducir a la mitad la pobreza extrema en el mundo en los últimos años, parecen contradecir lo que nosotros vemos y constatamos en la realidad. Cada vez es más presente y cruda la presencia de los pobres en nuestras sociedades, en nuestros países de América Latina, en el mundo. Los éxodos masivos en Oriente Medio, África, Asia y América Latina, hacia países más desarrollados, dan prueba de ello. La guerra, el narcotráfico y la corrupción política en varios países, han engrosado considerablemente el número de pobres en el mundo.

En México las cifras oficiales sobre la pobreza y el desempleo muestran una cara maquillada, sin embargo, la realidad muestra otra cara, más cruda, más presente, más real. Pareciera ser que la pobreza es una cosa y el pobre es otra. La pobreza son las cifras, las estadísticas, los números, el PIB de una nación. El pobre es Carmen, madre soltera que tiene que trabajar en lo que encuentre para mantener a sus tres hijos y que además es analfabeta; es Johnny, indocumentado hondureño que tiene que exponer su vida atravesando México, ya que ha preferido correr ese riesgo que morir de hambre o de violencia en su país. Y así podríamos citar muchos nombres, con rostros concretos, cuyas historias escapan, la mayoría de las veces, a los números oficiales, que buscan maquillar cifras. Consideramos por lo tanto que la lucha contra la pobreza es el mayor reto que tenemos que enfrentar las sociedades en la actualidad. Un desafío para la humanidad que debe encontrar en la ética la semilla que haga surgir tanto en políticos, religiosos, economistas, y sociedad en general, una nueva manera no tanto para ver sino para escuchar el clamor y el hambre del pobre (Cortina, 2017).

El objetivo de la presente reflexión es mostrar que la lucha contra la

Véase, http://www.bancomundial.org/es/topic/poverty/overview. 
pobreza económica y material, debe comenzar con un cambio de actitud individual que podemos llamar conversión o búsqueda de pobreza espiritual. Convertirnos al pobre no debe ser una opción política o religiosa entre otras más (una ideología política o una teología particular), sino que en esta conversión debemos encontrar el sentido mismo a nuestra existencia, y la posibilidad de vivir en una sociedad realmente justa y fraterna.

En nuestra reflexión, que tiene como finalidad pasar de la pobreza como problema a la pobreza como virtud, analizaremos en primer lugar el tema de la pobreza ligándolo al egoísmo humano, egoísmo que nos impide escuchar en el otro un rostro que tiene hambre y que nos pide justicia. En esta sección analizaremos cómo los modelos de sociedades postmodernas, neoliberales y hedonistas, que se promueven en la actualidad, nos impiden salir del egoísmo que solo sabe saciar su propia hambre y decir "yo soy", y olvida el hambre del otro. Posteriormente analizaremos el momento de la conversión cuando hace su irrupción el Otro, el pobre. Encuentro éticoreligioso, anterior al nacimiento de la política y de la economía, que nos debe llevar del yo-soy al "tú eres". Finalizaremos proponiendo una nueva forma de entender la pobreza no como un flagelo o imposición social a una gran parte de la humanidad, sino como una elección de vida, como una virtud. Lo que podríamos llamar la elección de una pobreza espiritual como condición necesaria para una vida plena, tanto a nivel personal como social, el poder decir: "Siendo pobre soy libre para amarte". El camino metodológico de nuestra exposición comprende tres etapas: egoísmo, conversión y elección.

\section{Pobreza y EGoÍSMO: UNA ECONOMÍA POSTMODERNA AL SERVICIO} DEL "YO SOY"

Emmanuel Levinas comienza su obra más conocida Totalidad e infinito (1961) con la frase siguiente: "Aceptaremos fácilmente que es cuestión de gran importancia saber si la moral no es una farsa" (Levinas, 1997: 47). Podríamos decir prácticamente lo mismo de la economía: "No es difícil aceptar que la economía hasta el día de hoy ha sido una farsa". Como dice Adela Cortina: "Una ciencia que no consigue que coman los seres humanos es un fracaso como ciencia" (Cortina, 2004: 11). ¿Por qué? Porque después de tantos siglos de tratados, ensayos, discursos y propuestas económicas, el ser humano no ha mejorado su situación material. Pareciera ser que la pobreza y la desigualdad social han sido constantes en la historia de la humanidad. Y si bien muchos pensadores han formulado propuestas sobre la ciudad, o el mundo ideal para que todos vivamos mejor (por ejemplo, Platón, Tomás Moro, Hobbes, Marx, etc.), estas propuestas se han quedado en utopías que no se han podido concretizar. ¿Por qué? Porque tal vez a la base del 
cambio social está el cambio, o la conversión individual. Tema poco tratado en economía y en general en la filosofía, ya que éstas por lo general ven al ser humano como representante de una colectividad social, un número, una cifra, una totalidad. El ser humano individual, que tiene un rostro concreto, se ha diluido en grandes proyectos económicos que han hablado a su espalda.

Vivimos en un mundo paradójico en que algunos -los que tienen el poder, fundamentalmente económico- hablan en nombre de la mayoría. El neoliberalismo salvaje parece homogeneizar al mundo gracias a la propaganda consumista omnipresente en todas partes, aún en las regiones más pobres del planeta. Es por esta razón que mientras algunos aseguran que vivimos en la actualidad en la postmodernidad, que es un desencanto de las promesas de la modernidad; los pobres -que son mayoría- experimentan que para ellos la modernidad todavía no les ha llegado. Vivimos en un mundo en que algunos hablan, buscando dar un sentido a sus vidas postmodernas, mientras que otros escuchan, y luchan por sobrevivir ya que son los invisibles de la historia. En 1961 Jean-Paul Sartre escribía en el prefacio al libro de Franz Fanon, Los condenados de la tierra, una frase que todavía tiene validez:

No bace mucho tiempo, la tierra estaba poblada por dos mil millones de babitantes, es decir, quinientos millones de hombres y mil quinientos millones de indigenas. Los primeros disponian del Verbo, los otros lo tomaban prestado. (2009: 7)

Como lo hemos mencionado anteriormente, el problema fundamental de la economía es que se ha ligado a la política y no a la ética, a la razón abstracta del yo y no a la escucha humilde del otro. A la pretensión de querer hablar en nombre de todos, de la colectividad, de la masa de seres humanos, pero olvidando relacionarse con el individuo concreto.

Cuando en 1979 Jean-François Lyotard introducía en filosofía el término de postmodernidad (Lyotard, 2004), él no estaba inventando nada nuevo, se trataba solo de una constatación sobre el espíritu de la época, l'air du temps. Una época que describe bien al hombre burgués contemporáneo, preocupado solo por él mismo, por su patrimonio, por su empresa, por su bienestar. La racionalidad inaugurada con Descartes, a partir de la búsqueda solipsista de su "cogito ergo sum" (pienso, luego existo), culmina con el triunfo de la razón. La postmodernidad, que surge como un desencanto por no haber logrado lo que la modernidad prometía, culmina con el triunfo del placer y la inmediatez: "compro, luego existo" (Cortina, 2002). Se pasó de la búsqueda de la verdad a la satisfacción del placer. Cambió la finalidad, pero no el lugar donde surge la inquietud: el todopoderoso Yo. 
¿Y qué tiene que ver todo esto con la economía? Consideramos que, si la economía no ha sabido hasta ahora responder al problema del otro, del prójimo, del pobre, es decir del ser humano que está frente a mí, es porque ha partido de las necesidades del yo, ya sean intelectuales o placenteras, pero siempre centradas en el yo. Es necesario buscar una nueva base, origen, arké, para la economía, que tome realmente en cuenta al otro; nos referimos a la ética. Pero no se trata de cualquier tipo de ética, sino de una ética particular, no surgida con Sócrates en Grecia, por ejemplo, que aún con buenas intenciones sigue partiendo del yo ligado a la razón (la mayéutica); sino de una ética llamémosle "espiritual", surgida con Abraham y posteriormente con el judeo-cristianismo, y ligada a la escucha. A una economía fundada en el Logos griego proponemos una economía que surja del Shema bíblico. Al deseo de una economía que busca inmediatamente "ver" y "hablar": mediante teorías, porcentajes y cifras; proponemos una economía que busque "escuchar" y "responder": mediante la justicia. ¿Pero cómo administrar la casa-común de manera distinta? ¿En qué momento hace su irrupción el otro, el pobre, en mi vida? Es aquí donde analizaremos brevemente la propuesta ético-bíblica del filósofo judío Emmanuel Levinas. Es importante remarcar que la crítica que ahora hacemos a una economía surgida únicamente de la razón, toma como base la crítica que Levinas hace a la ontología que sustenta a la política. En nuestro caso se trata de una ontología que fundamenta a la economía. En los dos casos, política y economía surgen de un yo egológico y ontológico que quiere ver para entender y explicar el mundo.

Para Emmanuel Levinas antes de que el Otro, a quien él da el nombre genérico de "rostro", surja en mi vida para llamarme, la primera preocupación en mi vida debe ser por mí mismo, por construir mi propio yo, mi casa, mi identidad. Es necesario e importante poder decir "yo soy" antes de llegar a decir "tú eres". En su libro mencionado anteriormente, Totalidad e infinito, Levinas consagra su capítulo II a describir la constitución del yo con un título muy elocuente: "Interioridad y economía". ¿Pero de qué economía se trata? De una economía que busca la correcta administración de la casa del yo. Para el filósofo francés nacemos egoístas y preocupados por saciar nuestra propia hambre. ¿Hambre de qué? De TODO. De cualquier "cosa" que encontremos a nuestro paso. Un todo genérico al que Levinas da el nombre de "Ser". Nos alimentamos del ser: música, comida, libros, espectáculos, etc., todo entra en nosotros y nos constituye. "Vivimos de "buena sopa", de aire, de luz, de espectáculos, de trabajo, de ideas, de sueños, etc...." (Levinas, 1997: 129). Levinas habla de economía para referirse a la manera como cada uno de nosotros administra en su vida interior al ser exterior que ha ido adquiriendo mediante el gozo de la asimilación y que le consti- 
tuye. Se trata por lo tanto de una economía puesta al servicio de la interioridad del yo, de mis gustos, creencias e intereses. Una economía que ignora el hambre del otro y que solo busca administrar el gozo del yo.

En el gozo, soy absolutamente para mí. Egoísta sin referencia al otro (...). No contra los otros, sino en mi "reserva personal" - pero enteramente sordo al otro, fuera de toda comunicación y de todo rechazo de comunicar- sin orejas, como vientre con hambre. (Levinas, 1997: 153)

El hombre egoísta que no escucha el clamor del hambre del otro, es como un vientre sin orejas que solo sabe comer. Ver con concupiscencia al otro para después devorarlo ya sea sexual, laboral, comercialmente, etc. Es el mundo de la economía liberal en que vivimos, en dónde como se dice coloquialmente: "el que tiene más saliva traga más pinole". Es a fin de cuentas el egoísmo humano el que explica que algunos coman mucho mientras otros se mueran de hambre; es el mundo de las grandes empresas transnacionales que hacen desaparecer a los pequeños comerciantes; de las grandes potencias que mantienen en la periferia a la mayoría de los países del orbe. Surge una pregunta importante: ¿cómo hacer para salir de esta óptica egoísta de provecho personal que olvida al otro? A través de lo que hemos llamado la conversión al otro.

2. POBREZA Y CONVERSIÓN: LA ACEPTACIÓN ÉTICA DEL OTRO EN MI VIDA, "TÚ ERES"

Lo único que nos puede salvar personal y colectivamente del egoísmo humano, que nos está llevando a construir sociedades sordas al clamor del otro, es la aceptación del otro/a en mi vida. Reconocer que no hemos venido para satisfacer nuestra propia hambre sino para poner nuestra vida misma al servicio del hambre del otro (Vaucher, Bourdin \& Durrer, 2012).

\subsection{El encuentro con el otro. "El otro es la fruta probibida"}

En el libro del Génesis, el Señor después de haber creado a Adán le dijo: "Puedes comer de cualquier árbol que haya en el jardín, menos del árbol de la Ciencia del bien y del mal; porque el día que comas de él morirás sin remedio" (Gn 2, 17). ¿Cuál es aquel árbol de la Ciencia del bien y del mal de cuyos frutos Dios ha prohibido comer a los hombres? Apoyándonos en los análisis de Emmanuel Levinas intentaremos demostrar que el otro, cualquier ser humano que se nos presente, constituye el fruto que nos está prohibido comer. 
Si estuviéramos solos en la tierra, como Robinson Crusoe en su isla antes del encuentro con Viernes, o Adán antes de la aparición de Eva, nuestra preocupación principal en la vida sería la de sobrevivir gracias a la comida. La comida constituye al hombre y lo nutre. El hombre es un ser omnívoro que se alimenta de todo lo que va encontrando a su paso. Comemos con la boca, pero también con los ojos, la nariz, los oídos y el tacto. Gracias a nuestros sentidos todo lo que hay fuera de nosotros y que podemos llamar "trascendencia" o exterioridad se convierte en alimento y pasa a formar parte de nosotros mismos, lo que podemos llamar "inmanencia" o interioridad. El alimentarnos y transmutar la exterioridad en interioridad no es un acto egoísta sino una necesidad vital. El Señor, después de haber creado al hombre le dijo que se alimentara de todo lo que encontrara en la creación: "Dios les dijo: "Yo les entrego, para que ustedes se alimenten, toda clase de bierbas, de semillas y toda clase de árboles frutales" (Gn 1, 29). El hombre nutre su cuerpo con la materialidad de la tierra, y nutre su espíritu con el conocimiento que le viene de las cosas que encuentra. "Y cada ser viviente habia de llamarse como el hombre lo habia llamado. El hombre puso nombre a todos los animales, a las aves del cielo y a las fieras salvajes" (Gn 2,20). Nombrar las cosas es conocerlas, asimilarlas, quitarles su misterio. Mediante la técnica el hombre domina al mundo y mediante la razón lo asimila, lo hace digerible. Nombrar es conocer y conocer es apropiarnos de las cosas, hacerlas nuestras. Dice Emmanuel Levinas, "La alimentación, como medio de revigorización, es la transmutación de lo Otro en Mismo, que está en la esencia del gozo" (Levinas, 1997: 130).

Existe una antropología bíblica antes y otra después de la aparición del otro. Antes de la creación de Eva, Adán tiene que preocuparse sólo por él, tiene que tener los dientes afilados para alimentar su cuerpo y los ojos limpios para nutrir su espíritu. La boca y la vista al servicio del crecimiento del yo. Y si con la boca comemos alimentos terrestres, con los ojos devoramos aquello que conocemos. La vista ha sido el órgano privilegiado en la historia de la filosofía porque ella nos permite sacar a las cosas de la oscuridad en que se encuentran (Loreau, 1989). "Idea", en griego, se dice eidos, es decir "aquello que yo he visto", aquello que yo poseo, que está dentro de mí. En el libro VII de la República, Platón equipara la idea del Bien con el Sol, ya que es la luz la que nos permite conocer las cosas como ellas son, su esencia, sacándolas de la noche de las apariencias y de la equivocidad. Dice Platón: "[la idea del bien] aparece al razonamiento como siendo en definitiva la causa universal de todo cuanto es recto y bello; que en el mundo visible, es ella la generatriz de la luzy del señor de la luz, y en el inteligible, a su vez, es ella misma la señora y dispensadora de la verdady de la inteligencia" (Platón, 2007: 246). 
¿Qué debemos concluir de todo esto para nuestra investigación? Que el hombre, al menos en la primera etapa de su formación, o de su constitución, debe preocuparse por comer con la boca y conocer con los ojos. En el libro del Génesis se nos dice que el hombre fue creado de barro y en la leyenda del Popol V uh, libro sagrado de los mayas, que fue hecho de maíz. Barro o maíz son los primeros elementos que nos constituyen. Sin embargo, nos podemos preguntar: ¿no hemos sido creados para algo más que no sea la asimilación a través del comer y del conocer? ¿Qué sucede cuando un ser humano se presenta a mí? ¿Lo considero objeto de comida y de conocimiento? Es aquí donde entra lo que hemos llamado anteriormente conversión al otro, o una manera nueva de relacionarnos con él/ella sin considerarlo mercancía u objeto para mi consumo. "Dijo Yabvé: "No es bueno que el hombre esté solo. Haré, pues, un ser semejante a él para que lo ayude" (Gn 2,18). La soledad es mala consejera, no es bueno que el hombre esté solo pensando en comer y conocer. Economía egoísta que ignora al otro. Necesitamos del otro/a que nos venga a ayudar, es decir a sacarnos de nuestro sueño de autosuficiencia, alguien que venga a romper la unidad y la dureza de nuestro yo. Alguien que venga no para que yo lo coma con mis dientes o mis ojos, sino alguien, que al contrario venga a comer algo de mí, venga para que yo le dé algo de lo mío, economía del servicio al otro. "Entonces Yabvé bizo caer en un profundo sueño al hombre y éste se durmió. Y le sacó una de sus costillas, tapando el hueco con carne. De la costilla que Yabvé habia sacado al hombre, formó una mujer y la llevó ante el hombre" (Gn 2, 21-22). El hombre definitivo -O "completo", por utilizar esta palabra- es aquel que ya no está hecho solamente de barro sino de la alteridad del otro. Eva está formada de la costilla de Adán y no solamente de barro. Pero, ¿cómo se llega a la creación de un ser humano a partir de otro? Mediante la aceptación de la alteridad (Correa, 2013). Es decir, aceptando que el otro, cualquier ser humano que esté enfrente de mí, no es objeto de consumo para mi boca o para mis ojos, sino que es la fruta prohibida que no viene a entrar en mí por medio de la alimentación, sino que viene a sacarme de mí, de mi egoísmo, para que sea yo quien lo alimente a él o ella.

Hay, por lo tanto, un cambio radical en la manera de entender la economía, no ya como una preocupación por la administración de mi propia hambre, sino como una preocupación por saciar el hambre del otro. Para Emmanuel Levinas, cuando el rostro se me presenta, lo primero que me dice es: “iNo matarás!” es decir: ¡Ten cuidado, yo no soy comestible, no me confundas con las frutas del paraíso! "Dios le dio esta orden al hombre: "Puedes comer de cualquier árbol que haya en el jardín, menos del árbol de la Ciencia del bien y del mal; porque el día que comas de él, morirás sin remedio" (Gn 2, 17). Si el otro es la fruta prohibida que yo no puedo comer, y yo estoy tan acos- 
tumbrado a comer, asimilar, y hacer desaparecer todo aquello que esté enfrente de mí, nos podemos preguntar: ¿cómo se puede llegar a respetar la alteridad del otro? Es aquí donde hablaremos de la huella de Dios en el rostro del otro que me ordena servirlo. Escucha ética del rostro del otro que permite mi conversión al otro.

2.2. De la asimilación del otro a la donación del yo. "Ya no soy yo quien vive, es Cristo quien vive en mí" (Gal 2, 20a)

Si anteriormente hemos dicho que los dos órganos privilegiados para realizar el proceso de asimilación, o de transmutación de lo otro en mí mismo, son la boca y los ojos, Emmanuel Levinas, a partir de las fuentes bíblicas, nos va enseñar a agudizar un sentido que hemos descuidado mucho en filosofía y en las relaciones humanas y que es el sentido del oído. ¿Por qué el oído? Porque el oído es el sentido de la alteridad que nos permite escuchar el llamado del otro. Mientras que en filosofía se nos ha enseñado que el órgano por excelencia es la vista, que nos permite ver y comprender, en la Biblia el oído es el sentido privilegiado para entrar en relación con Dios. Tanto en el Antiguo Testamento con el jShema Israel! (iEscucha Israel!) (Dt 6, 4), como en el Nuevo Testamento con tantas exhortaciones a escuchar al Señor: "El que tenga oídos para oír que oiga!" (Mc 4, 23; Lc 8, 8), "El que los escucha a ustedes me escucha a mi" (Lc 10, 16), etc.

Para Levinas, Dios nos habla a través del rostro del otro, de cualquier ser humano que esté enfrente de mí. Llamado que viene a constituir mi vida y a orientar mi pensamiento para otorgarme mi verdadera identidad. Una identidad no enraizada en el egoísmo del yo que se preocupa por su propia alimentación, sino en la preocupación por el hambre del otro. "Quitarme el pan de la boca para que el otro coma”, decía Levinas. O, más aún, las palabras de Cristo en los evangelios, que se ofrece en sacrificio para que el mundo tenga vida: "Yo soy el pan de vida. El pan que yo les daré es mi carne, y la daré para la vida del mundo" (Jn 6, 48.51), o "Esto es mi cuerpo, que es entregado por ustedes" (Lc 22, 19). ¿Cómo se llega a este auto-sacrificio, o inmolación del yo, en beneficio del tú? Realizando el paso del egoísmo del yo a la responsabilidad por el otro. Un paso que no es automático, sino que necesita de un proceso de maduración humana que, en términos religiosos, se dice conversión.

En la filosofía de Emmanuel Levinas, la primera experiencia desconcertante de alteridad es la experiencia erótica y amorosa. ¿Por qué? Porque antes de una verdadera experiencia amorosa, el hombre (o la mujer) está acostumbrado a poseer a los otros, a comerlos, como si fueran frutos del paraíso que están a su disposición. Comer al otro es ignorarlo como rostro, hacerlo girar en la órbita de mis intereses, de mis deseos, no respetar su 
alteridad infranqueable (Bauman, 2015). Sin embargo, surge un día en que el yo se descubre vulnerable en el amor. El otro comienza a hacer girar su vida y sus intereses en torno de ella (o de él). Surge el enamoramiento. Y más el amor es intenso, más el dolor de la separación es grande. En la experiencia erótica y sensible del erotismo se vive la paradoja del amor: la posesión y la pérdida del otro. Hambre siempre insatisfecha del cuerpo del otro, momentos efímeros de delirio en donde se creyó, en donde se sintió, haberse apropiado del otro, que a pesar de todo permanece afuera, otro que yo. Se quiere comer al otro a besos, devorarlo en el acto sexual y sin embargo permanece fuera de mí, otro que yo. Levinas realiza un análisis de la caricia erótica y escribe:

La caricia como el contacto es sensibilidad: Pero la caricia trasciende lo sensible. (...). La caricia consiste en no apresar nada, en solicitar lo que se escapa sin cesar de su forma hacia un porvenir -jamás lo bastante porvenir-, en solicitar eso que se oculta como si no fuera aún. Busca, registra. No es una intencionalidad de develamiento, sino de búsqueda; marcha hacia lo invisible. En cierto sentido expresa el amor, pero sufre por la incapacidad de decirlo. (Levinas, 1997: 267-268)

Sin embargo, para Levinas en la experiencia erótica y amorosa, todavía no nos encontramos con la experiencia profunda de la alteridad. ¿Por qué? Porque en el intercambio erótico y amoroso hay reciprocidad, yo me "alimento" de ella y ella se alimenta de mí. Economía de intercambio de necesidades. Intento fallido de una fusión que no llega, pero que invita a los enamorados a querer morir en el intento de comerse, de devorarse mutuamente. Para Levinas, la experiencia de alteridad por excelencia me viene del encuentro con aquel (o aquella) que yo no puedo devorar, que yo no puedo morder, para apropiarme algo de él o de ella, es el encuentro con la fruta prohibida del rostro del otro. Economía del don y de la gratuidad distinta a la economía del beneficio (Benedicto XVI, 2009; Bruni, 2010).

Si en el libro del Génesis se nos habla de una fruta que no debemos comer, para Levinas esta fruta corresponde al rostro del otro. Levinas elige el término "rostro" para hablarnos de la presencia física de cualquier ser humano. ¿Por qué rostro? No hay que olvidar que en el Antiguo Testamento la palabra rostro se utiliza para referirse a Dios, a su esencia, a lo que Él mismo es. Por lo tanto, no se puede ver el rostro de Dios. ¿Quién puede ver el rostro de Dios y permanecer en vida? A Dios no se le puede ver con los ojos de la razón (es decir, entenderlo), ni menos aún devorarlo con la boca (es decir, apropiárnoslo). Con Dios lo único que podemos hacer es escucharlo, es decir, obedecerlo y servirlo. Para Levinas, y en fi- 
delidad a la Biblia, Dios nos habla a través del hombre. El rostro de cualquier ser humano que yo encuentre en mi camino, constituye el Sinaí, la montaña, o epifanía sagrada, a partir de la cual Dios me manda escucharlo y obedecerlo. "Yahvé vio que Moisés se acercaba para mirar, y Dios lo llamó de en medio de la zarza: "Moisés, Moisés". El respondió: "Aqui estoy". Yabvé le dijo: "No te acerques más. Sácate tus sandalias porque el lugar que pisas es tierra sagrada" (Ex $3,4-5)$. Ahora bien, es importante señalar aquí que el rostro del otro no es Dios, pero es el único camino que tenemos para llegar a Él. El rostro es la huella de Dios. Si no encontramos la huella de Dios en las relaciones humanas no la encontraremos en ninguna parte. "Entonces los buenos preguntarán: "Señor, ¿cuándo te vimos hambriento y te dimos de comer; sediento y te dimos de beber (...)?" El Rey responderá: "En verdad les digo que cuando lo bicieron con alguno de estos mis hermanos más pequeños, lo bicieron conmigo" (Mt 25, 37-40) (Sánchez, 2006a).

Resumiendo, podemos decir que, si la economía hasta ahora no ha sabido responder a las expectativas humanas de construir una sociedad más equilibrada y justa, es porque ha estado fundada en una razón egoísta que sólo se ha preocupado por saciar el hambre del yo. Es necesario buscar un nuevo fundamento a la economía que tome en cuenta el hambre del otro. Una economía que surja, no de la razón, de los cálculos y de las estadísticas, sino de la pasión, de la compasión y más aún del amor por el otro (Nussbaum, 2014). Una economía en la cual la pobreza sea una elección de vida.

3. Pobreza y ELECCiÓn: De la pobreza impuesta A LA POBREZA DESEADA, "SIENDO POBRE SOY LIBRE PARA AMARTE"

En esta última sección reflexionaremos sobre la pobreza no como imposición sino como elección de vida. Normalmente pensamos en la pobreza en términos negativos: miseria, hambre, opresión, etc. ¿Pero no hay también en la pobreza elementos positivos? No nos referimos aquí a la pobreza que deshumaniza y que debemos evitar, sino a la pobreza que humaniza y que debemos buscar. Nos referimos a la pobreza no como problema sino como virtud. Se trata de una pobreza que nos da libertad, tranquilidad, paz, y que contribuya para construir un mundo más fraterno y justo.

\subsection{La pobreza como virtud y no como problema}

No hay que olvidar que en la historia de la humanidad grandes hombres como filósofos, artistas, políticos y sobre todo santos, se han revelado 
contra sistemas que, buscando el bienestar puramente material y económico del ser humano, terminan por asfixiarlo y destruirlo. Y esto se puede aplicar tanto a sistemas de izquierda como de derecha, tanto al comunismo como al neo-liberalismo salvaje. En el presente trabajo sólo mencionaremos el caso de la filosofía y de la espiritualidad, como defensoras de una pobreza que libere y que promueva al ser humano.

\subsubsection{Los filósofos y la pobreza}

En el ámbito de la filosofía citaremos dos casos: Sócrates, en los orígenes de la filosofía clásica, y Martin Heidegger, considerado por algunos como el más grande pensador del siglo XX.

A) Sócrates y la pobreza como búsqueda de un bien superior que es la Verdad. Sócrates (470-399 a.C.) está considerado como el fundador de la moral occidental. Para Sócrates la moral que busca una vida noble y elevada debe despreciar la riqueza, ya que ésta impide al ser humano elevarse a cosas superiores en vista de cosas efímeras. En la Apología de Sócrates, Platón escribe las siguientes palabras que su maestro Sócrates pronuncia para defenderse de las críticas que se le hacen de pervertir a los jóvenes:

Yo, atenienses, os aprecio y os quiero, pero voy a obedecer al dios más que a vosotros y, mientras aliente y sea capaz, es seguro que no dejaré de filosofar, de exhortaros y de hacer manifestaciones al que de vosotros vaya encontrando, diciéndole lo que acostumbro: "Mi buen amigo, siendo ateniense, de la ciudad más grande y más prestigiada en sabiduría y poder, ¿no te avergüenzas de preocuparte de cómo tendrás mayores riquezas y la mayor fama y los mayores honores, $y$, en cambio no te preocupas ni interesas por la inteligencia, la verdad y cómo tu alma va a ser la mejor posible?” (Platón, 2010: 17-18)

Sócrates no ve la pobreza como un problema social sino como una virtud ética. La pobreza, es decir el desapego de las cosas materiales nos permite centrarnos en lo esencial: la búsqueda de la verdad y de la justicia (Sánchez, 2006b). Comentan los biógrafos de Sócrates, que al filósofo griego le causaba gran alegría recorrer el mercado de Atenas y ver cuántas cosas allí se vendían que él no necesitaba. Es decir, para él, rico no era el que más tenía, sino el que menos necesitaba. A la muerte de Sócrates, los amantes de la sabiduría relacionarán la pobreza con la búsqueda de la verdad. Tal es el caso de los cínicos, escuela filosófica que floreció en la segunda mitad del siglo IV a.C., teniendo como uno de sus principales representantes a Diógenes de Sinope, también llamado Diógenes "el cínico". 
Diógenes, siendo hijo de un banquero y fabricante de monedas, optó por la pobreza llevándola hasta el límite de la miseria y del descuido de él mismo. Es conocido el encuentro que tuvo Alejandro Magno con Diógenes, cuando el gran conquistador y alumno de Aristóteles quiso visitarlo en la tinaja donde Diógenes vivía.

El político queriendo hacer un bien al filósofo, se inclinó para mirarlo en su tinaja y le preguntó: - “QQué quieres que haga por ti?” Diógenes mirándolo con enojo le contestó: - "Que te quites de mí porque me tapas el sol". Algunos pensaron que Alejandro se molestaría, pero éste les comentó: - "Si no fuera yo Alejandro, me gustaría ser Diógenes”. (Laercio, 2003: 186)

B) Heidegger, la pobreza como condición existencial para la búsqueda del Ser. De los primeros pensadores occidentales, pasemos ahora a analizar muy brevemente a uno de los más grandes filósofos del siglo XX, Martin Heidegger. Y si en los albores de la filosofía los primeros pensadores encontraron en la pobreza una condición necesaria para la búsqueda de la Verdad, Martin Heidegger muchos siglos después, retomará esa misma necesidad como condición existencial para la búsqueda del Ser. Heidegger identifica el Ser con la Verdad y para el pensador alemán solo podemos acceder al Ser siendo libres. En 1945, cuando Alemania había perdido la guerra y había quedado en extrema pobreza y humillación, Heidegger dictó una breve conferencia para analizar un verso del Himno del poeta Hölderlin, El Ister. El verso dice así: "Entre nosotros, todo se concentra en lo espiritual, nos hemos vuelto pobres para llegar a ser ricos" (Heidegger, 2006: 93).

Heidegger al analizar el verso del poeta hace la diferencia entre lo material y lo espiritual. Material es todo lo que es, lo ente. Y espiritual es lo más sublime a lo que pueda aspirar el ser humano. ¿Y qué es lo más sublime en el hombre? La búsqueda del Ser.

A lo que de ordinario nos rodea, los objetos particulares, lo llamamos también ente, lo que es. Pero este "es" en el nivel del ente no es a su vez algo del ente, sino lo que deja primero a todo ente ser un Ente y por esto lo rodea de cuidados y lo protege. Lo llamamos Ser. La relación sublime en que el hombre está es la relación del Ser con el hombre. (Heidegger, 2006: 103)

Para Heidegger ser pobre es ser libre para buscar lo único necesario que es el Ser. El riesgo de la pobreza material, es decir, aquella que es impuesta por otros, es que solo busca satisfacer las necesidades básicas: comer, vestirse, cuidar la salud, etc. ¿Pero todo esto para qué? ¿Para qué vivimos? "El peligro de la hambruna, por ejemplo, y de los años de escasez, si se considera en su totalidad lo propio del destino occidental, no reside de ningún modo en 
que muchos hombres puedan perecer, sino en que aquellos que se salvan no viven más que para comer a fin de vivir" (Heidegger, 2006: 117). En conclusión, para Heidegger Occidente se equivoca cuando piensa que es erradicando la pobreza material que el mundo será más feliz, como es el caso del comunismo, sino que realmente se debe despertar otro tipo de pobreza espiritual que es la que nos hará más humanos y nos enriquecerá. "Pobres, no nos volveremos por lo que, bajo el nombre inadecuado de "comunismo", se anuncia como el destino del mundo historial. Pobres, lo somos con la única condición de que, entre nosotros, todo se concentre sobre lo espiritual" (Heidegger, 2006: 117).

\subsubsection{La pobreza como condición espiritual para el encuentro con Dios}

Podríamos seguir citando a otros hombres y mujeres que, perteneciendo a diferentes ramas del saber y de distintas confesiones religiosas, han encontrado en la pobreza la condición necesaria para ser libres y buscar así fines más elevados y sublimes; sin embargo, solo comentaremos brevemente a dos religiosos católicos: Francisco de Asís y Bartolomé de las Casas.

A) Francisco de Asís y su amor por la dama pobreza. Francisco (1181-1226) vivió en la ciudad de Asís, en la región de Umbría, Italia, en plena edad media. Francisco fue hijo de un rico comerciante en telas que dio todos los lujos necesarios a su hijo. Sin embargo, después de regresar éste derrotado de las cruzadas, a donde había ido con la finalidad de regresar con el título de caballero, tuvo una experiencia espiritual que cambió su vida para siempre.

Francisco regresa de la batalla derrotado, pero no solo política y socialmente sino sobre todo humana e individualmente. En la guerra se dio cuenta de la superficialidad y de la banalidad de la búsqueda de glorias y de bienes materiales. ¿Vivir para qué? ¿Para conseguir títulos y riquezas? Francisco entra en una fuerte depresión existencial sobre el sentido último de su vida. Y es gracias al contacto con la naturaleza, con el sol, la lluvia, los animales y las flores silvestres, que comienza a encontrar la verdadera riqueza de la vida gracias al contacto con la naturaleza, con él mismo y finalmente con Dios. Francisco sabe qué es lo que "no quiere ser" (una persona egoísta que sólo desea poseer bienes y riquezas materiales incluso a costa de la muerte), pero aún no sabe qué es lo que "sí quiere ser". Y es una mañana de verano mientras él oraba a un Cristo bizantino en la vieja y derruida ermita de San Damián, que Francisco escuchó en su interior la voz de Cristo que le dijo: "Francisco repara mi Iglesia". Francisco al principio creyó que se trataba de restaurar físicamente el viejo y maltratado templo en el cual él se encontraba. Sin embargo, era un llamado superior para 
reparar la Iglesia de Cristo que amenazaba con caerse por haberse dejado corromper por el poder y las riquezas materiales. Francisco, uno de los grandes santos de la Iglesia, patrón de la ecología (Francisco, 2015) y restaurador de la Iglesia, consigue gracias a su amor por la pobreza, a quien él llamaba "Dama pobreza", regresar a la Iglesia querida por Jesucristo. Una Iglesia pobre centrada en la búsqueda del Reino de Dios. Éloi Leclerc, en su libro Sagesse d'un pauvre, recuerda las palabras de Francisco a uno de sus hermanos:

El trabajo no lo es todo, hermano León, no lo resuelve todo. Puede incluso convertirse en obstáculo para conseguir la verdadera libertad del hombre. Se convierte en obstáculo cada vez que el hombre se deja acaparar por su obra hasta el punto de olvidar adorar a Dios vivo y verdadero. (Leclerc, 1991: 122)

B) Bartolomé de las Casas y la defensa del indio desde su testimonio de pobreza. Después de haber comentado brevemente el amor por la pobreza en el fundador de los franciscanos, pasemos ahora a analizar algunos elementos biográficos de uno de los padres dominicos más destacados que es Fr. Bartolomé de las Casas.

Bartolomé de las Casas (1474 ó 1484-1566) nació en Sevilla, España, y al igual que Francisco de Asís -antes de su conversión- también él busco honores y riquezas materiales. Llegó al "nuevo mundo" a la edad de 18 años con la ilusión de hacerse de un patrimonio como la mayoría de los españoles que llegaban al continente recién descubierto (Bataillon, 2013). Sin embargo, hubo tres elementos que lo llevaron a cambiar de dirección en su vida, a convertirse a la causa de los indios: la experiencia de muerte que él vivió, la lectura de la Biblia desde la óptica de los pobres y el testimonio de los padres dominicos (Latapí, Cuetos \& Piñón, 2016).

1. La experiencia de muerte. Las Casas al igual que Francisco fue testigo de la muerte del otro con el afán de conquistar honores y riquezas en las batallas. Las Casas participó como clérigo-conquistador en las atrocidades que se estaban llevando a cabo en el nuevo continente. Algunos años después de lo que podríamos llamar su "conversión" a los indios, él escribirá su Brevísima relación de la destrucción de las Indias. Texto que, como su nombre mismo lo indica, quiere presentar de forma muy breve, pero detallada, la manera en que se estaban destruyendo las indias. El texto, escrito en 1542, inicia con las siguientes palabras:

Todas las cosas que han acaescido en las Indias, desde su maravilloso descubrimiento y del principio que a ellas fueron españoles para estar tiempo alguno $(. .$.$) han sido tan admirables y tan no creíbles en todo género a quien$ 
no las vido que parece haber añublado y puesto silencio y bastantes a poner olvido a todas cuantas por hazañosas que fuesen en los siglos pasados se vieron y oyeron en el mundo. Entre éstas son las matanzas y estragos de gentes inocentes. (Las Casas, 2008: 3, 8 y 10)

Las Casas no quiere seguir siendo cómplice de la masacre que se estaba cometiendo en el nuevo mundo y es así que el 15 de agosto de 1514, y ya siendo sacerdote, renuncia públicamente a las tierras y a los indios que se le habían confiado para su explotación.

2. La lectura de la Biblia desde los pobres. Un segundo elemento que contribuye para su conversión es la lectura que él hace de la Biblia, pero a partir de la óptica de los pobres. En particular hay un texto bíblico que leyó en abril de 1514 y que motivó su conversión definitiva algunos meses más tarde. Eclesiástico 34, 21-22: "El pan de los necesitados es la vida de los pobres, privarlos de su pan es cometer un crimen. Quitar al prójimo su sustento es matarlo, privarlo del salario que le corresponde es derramar su sangre" (Gutiérrez, 1993). Una vez que Las Casas ha identificado el sufrimiento del indio con el sufrimiento de Cristo, él leerá la Biblia a partir de la vida, pasión y muerte del indio.

3. El testimonio de los frailes dominicos. Un tercer elemento en el proceso de su conversión fue su ingreso a la orden de los dominicos en 1520, seis años después de haber renunciado a los indios que él poseía. Una vez que Las Casas había hecho suya la defensa de los indios, encontrará en la orden de los padres predicadores, un testimonio de vida de lo que significa anunciar el Evangelio a los más débiles. En diciembre de 1511, un año después de haber llegado a la isla y pocos días antes de la Navidad, los padres dominicos eligieron a su mejor predicador, fray Antonio de Montesino, e invitaron a todos los encomenderos y residentes de la isla a participar con especial atención a la misa que celebrarían ese cuarto domingo de Adviento, ya que tenían un mensaje muy importante que trasmitirles.

En esa misa Fray Antonio de Montesino pronunció lo que para muchos está considerado como el primer gran discurso en defensa de los indios en el continente americano. En el Evangelio de ese cuarto domingo de Adviento se había leído el Evangelio de Juan que dice: "Yo soy la voz que clama en el desierto" (Jn 1, 23). Fray Antonio de Montesino contextualizó el mensaje del profeta Juan el Bautista a la situación de injusticia que vivían los indios y dijo:

Para os los dar a cognoscer me he sobido aquí, yo que soy voz de Cristo en el desierto desta isla, y por tanto, conviene que con atención, no cualquiera, sino con todo vuestro corazón y con todos vuestros sentidos, la oigáis; la cual voz os será la más nueva que nunca oísteis, la más áspera y dura y más 
espantable y peligrosa que jamás no pensasteis oír. Esta voz, dijo él, que todos estáis en pecado mortal y en él vivís y morís, por la crueldad y tiranía que usáis con estas inocentes gentes. Decid, ¿con qué derecho y con qué justicia tenéis en tan cruel y horrible servidumbre aquestos indios? (...) ¿Estos no son hombres? ¿No tienen ánimas racionales? ¿No sois obligados a amallos como a vosotros mismos? ¿Esto no entendéis? ¿Esto no sentís? ¿Cómo estáis en tanta profundidad de sueño tan letárgico dormidos? Tened por cierto, que en el estado en que estáis no os podéis más salvar que los moros o turcos que carecen y no quieren la fe de Jesucristo. (Jiménez \& Romero, 2012: 165-166)

Las Casas escuchó el famoso "Sermón de Montesinos", que le marcará profundamente y que él mismo transcribirá en sus obras. El compromiso de los padres dominicos hizo que Bartolomé de las Casas ingresara a la orden de Santo Domingo en 1520.

\section{CONCLUSIÓN}

Iniciamos el presente ensayo preguntándonos por qué hasta ahora no se ha podido combatir la pobreza material y económica en el mundo. La brecha que separa a ricos de pobres es cada vez mayor a pesar de las buenas intenciones de varios organismos internacionales. En el transcurso de nuestro trabajo hemos analizado que a la base de le economía no deben situarse intereses políticos o personales, sino una preocupación ética y social por el bienestar del otro, que tome en cuenta su dignidad. Hemos hablado de dos formas distintas y hasta opuestas de entender la pobreza, sea como problema o sea como virtud.

La pobreza como problema implica un desafío para las sociedades contemporáneas. Luchar por combatir la pobreza económica es el mayor reto de las sociedades desarrolladas, subdesarroladas (y maldesarrolladas). Y este combate no se logra creando guetos ni construyendo murallas, sino rompiendo el gueto y la muralla principal que es el egoísmo. La pobreza como virtud implica no dejarse encadenar por los mecanismos de la sociedad consumista en la que ahora vivimos, que lejos de liberarnos nos esclaviza a las cosas. Vivimos en una sociedad donde el amor por las cosas (automóviles, teléfonos, artefactos tecnológicos, etc.) es más fuerte e importante que el amor por la vida y por las personas. "El compre y tire" es el nuevo motor que impulsa a las sociedades actuales, y en este deseo compulsivo de posesión se nos va la vida personal, familiar y colectiva. Para tratar de demostrar cómo el cambio hacia una sociedad más justa y fraterna comienza con el cambio en uno mismo, que hemos llamado "conversión" al otro, hemos dividido nuestro trabajo en tres apartados. 
En pobreza y egoísmo hemos analizado la pobreza material como un mal social fruto del egoísmo humano. Thomas Hobbes decía a mediados del siglo XVII que "el hombre es un lobo para el hombre". Es decir que cada ser humano siempre estará en guerra contra los demás con tal de satisfacer sus propios apetitos de posesión. ¿Es esto verdad? ¿La historia de la humanidad es y será una historia de guerra, de muerte y de violencia? Para lograr vencer el egoísmo humano que sólo sabe decir "yo soy", es necesario escuchar al otro éticamente y pasar del "yo soy, al tú eres", tema analizado en la segunda sección de nuestro trabajo: pobreza y conversión. Poner la economía y la vida misma al servicio del otro requiere de un proceso de cambio que hemos llamado “conversión”. En la última sección de nuestro trabajo, que es la más extensa y central de nuestro estudio: pobreza y elección, hemos analizado la pobreza no como falta sino como plenitud. La pobreza económica no solo deshumaniza y mata al pobre sino también al rico. Al pobre porque le impide vivir y desarrollar sus capacidades (Sen, 2013a y 2013b; Nussbaum, 2012), y al rico porque lo mantiene esclavo de sus propias posesiones. En este último apartado hemos comentado el pensamiento de dos filósofos y de dos religiosos. Tanto para Sócrates como para Heidegger, la pobreza es la condición indispensable, para poder ser libres y encontrar la Verdad en el caso del primero y el Ser en el caso del segundo. Esta misma relación pobreza = libertad la encontramos en los religiosos Francisco de Asís y Fray Bartolomé de las Casas.

El combate contra la pobreza económica y por una sociedad más justa y fraterna, antes de jugarse en el terreno de la economía y de la política, se juega en el corazón de cada hombre. Una elección de vida que nos permite decir: "Siendo pobre soy libre para amarte".

\section{REFERENCIAS}

Bataillon, M. (2013). Las Casas en la bistoria. México: Fondo de Cultura Económica.

Bauman, Z. (2015). Amor liquido. Buenos Aires: Fondo de Cultura Económica.

Benedicto XVI. (2009). Carta encíclica Caritas in veritate, sobre el desarrollo humano integral en la caridad y en la verdad. Disponible en http:/ / www.vatican.va/content/benedict-xvi/es/encyclicals/documents/hf_benxvi_enc_20090629_caritas-in-veritate.html

Bruni, L. (2010). La herida del otro. Economía y relaciones bumanas. Madrid: Ciudad Nueva.

Canto-Sperber, M. (2011). Diccionario de ética y filosofía moral. México: Fondo de Cultura Económica.

Correa, M. (2013). Antropología dialógica. Una aproximación desde Martin Buber. En L. M. de la Maza y A. Covarrubias (Eds.), Realidad humana e ideal de bumanidad (pp. 158-171). Santiago de Chile: Ediciones UC. 
Cortina, A. (2002). Por una ética del consumo. Madrid: Taurus.

Cortina, A. (2004). Viabilidad de la ética en el mundo actual. México: Universidad Iberoamericana Puebla.

Cortina, A. (2017). Aporofobia, el rechazo del pobre. Barcelona: Paidós.

Fanon, F. (2009). Los condenados de la tierra. México: Fondo de Cultura Económica. Francisco. (2015). Laudato si. México. PPC.

Gutiérrez, G. (1993). En busca de los pobres de Jesucristo. Salamanca: Sígueme.

Heidegger, M. (2006). La pobreza. Buenos Aires: Amorrortu.

Jiménez, R. \& Romero, M. (2012). 500 años de lucha por la justicia. Santo Domingo: Universidad Autónoma de Santo Domingo.

Laercio, D. (2003). Vidas de los filósofos más ilustres. México: Porrúa.

Las Casas, B. (2008). Brevísima relación de la destrucción de las Indias. Madrid: Tecnos.

Latapí, A; Cuetos, L. \& Piñón, F. (2016). Ética, política y bumanismo en los frailes dominicos. A 800 años de la fundación de la Orden de los Predicadores. México: Centro Gramsci.

Leclerc, E. (1991). Sagesse d'un pauvre. Paris: Desclée de Brouwer.

Levinas, E. (1997). Totalidad e infinito. Salamanca: Sígueme.

Loreau, M. (1989). La genèse du phénomène. Le phénomène, le logos, l'origine. Paris: Éditions de minuit.

Lyotard, J.-F. (2004). La condición postmoderna. Madrid: Cátedra.

Nussbaum, M. (2014). Emociones políticas. ¿Por qué el amor es importante para la justicia? Barcelona: Paidós.

Nussbaum, M. (2012). Crear capacidades. Madrid: Paidós.

Platón. (2007). La República. México: UNAM.

Platón. (2010). Apología de Sócrates y otros textos. Madrid: Gredos.

Sánchez, F. (2006a). ¿Cómo hablar de Dios al hombre de hoy? México: Universidad Pontificia de México.

Sánchez, F. (2006b). La verdad y la justicia. El llamado y la respuesta en la filosofía de Levinas. México: Universidad Pontificia de México.

Sen, A. (2013a). Desarrollo y libertad. México: Taurus.

Sen, A. (2013b). La idea de justicia. México: Taurus.

Vaucher, M; Bourdin, D; Durrer, M. \& Revaz, O (Ed.). (2012). Foi de cannibale! La dévoration, entre religion et psychanalyse. Genève : Labor et fides.

Sumario: Introducción. 1. Pobreza y egoísmo: una economía postmoderna al servicio del "yo soy"; 2. Pobreza y conversión: la aceptación ética del otro en mi vida: "tu eres"; 2.1. El encuentro con el otro. "El otro es la fruta probibida"; 2.2. De la asimilación del otro a la donación del yo. "Ya no soy yo quien vive, es Cristo quien vive en mi" (Gal 2, 20a); 3. Pobreza y elección: De la pobreza impuesta a la pobreza deseada. "Siendo pobre soy libre para amarte"; 3.1. La pobreza como virtud y no como problema; 3.1.1. Los filósofos y la pobreza; 3.1.2. La pobreza como condición espiritual para el encuentro con Dios; Conclusión; Referencias. 